Mgr Lukasz Blechar

Uniwersytet Marii Curie-Skłodowskiej

e-mail: 1.blechar@gmail.com

\title{
Problemy współczesności. Recenzja książki Re-Engineering Humanity autorstwa Bretta Frischmanna i Evana Selingera
}

Książka Re-Engineering Humanity jest dziełem wieloaspektowym, ambitnie rzucającym wyzwanie odbiorcy, skłaniającym go, by dostrzegł subtelne mechanizmy zaszyte w naszej codzienności. Publikacja Bretta Frischmanna i Evana Selingera wymyka się prostym, zdecydowanym klasyfikacjom. Pobrzmiewają w niej zarówno nuty wiedzy deskryptywnej, jak i normatywnej. Tworzy ona skomplikowaną mozaikę przeplecionych ze sobą opisów technologii, stanowisk filozoficznych, wypowiedzi anegdotycznych i kończy się zestawem zaleceń, jak możemy przeciwdziałać bardzo precyzyjnie zarysowanemu zagrożeniu, jakim jest coraz częstsze myślenie zarówno o ludziach, jak i o maszynach. Niemożliwe jest przyporządkowanie jej konkretnemu nurtowi badawczemu czy dziedzinie naukowej. Poruszane $\mathrm{w}$ niej tematy są bowiem rozpięte $\mathrm{w}$ różnym stopniu między naukami społecznymi, inżynieryjnymi, prawnymi, poznawczymi, behawioralnymi czy humanistycznymi. Wynika to z rozpatrywanej problematyki, gdyż przedstawiane sytuacje również są trudne do jednoznacznego opisania, nie mówiąc już o wskazaniu możliwości ich ewaluacji. Autorom udaje się jednak zwinnie poruszać po meandrach współczesności i eksponować jej ukrytą dla większości ludzi głębię.

Warto zacząć od względów bardziej formalnych. Struktura książki została zaprojektowana w sposób prosty i klarowny. Mamy tu do czynienia z czterema rozdziałami, określanymi jako części (parts). Mimo wyraźnego zróżnicowania tematycznego autorzy nie pokusili się o obdarzenie ich konkretnymi tytułami. Kwestią budzącą zdziwienie jest wyróżnienie wprowadzenia (Introduction) jako niepełnoprawnej części, lecz pozostawienie konkluzji przyporządkowanej części czwartej (Part IV). Ponadto, umieszczono po nich pięć dodatków (Appendix - od $A$. do $E$.) rozwijających nieco szerzej (zajmujących od dwóch do sześciu stron) 
tematy zasygnalizowane w głównej części publikacji. Następnie przedstawione zostały krótkie, jedno- lub dwuakapitowe, wyjaśnienia skrótów myślowych z głównej części książki. Ostatnim elementem publikacji jest obszerna bibliografia.

Głównym problemem poruszanym po wielokroć w książce jest trudna relacja między ludźmi a technologią. Nasza uwaga zostaje zwrócona na fakt, że to właśnie dzięki technologii udało nam się wznieść na szczyt łańcucha pokarmowego. O ile takie stwierdzenie nie budzi wątpliwości, o tyle autorzy posuwają się dalej, sugerując trudniejsze do zaakceptowania teorie. Zakładają, że technologia umożliwia nam wyrwanie się tak zwanym okowom biologicznym. Co więcej, postulują jakobyśmy byli na tyle dojrzałymi użytkownikami technologii, że jesteśmy dzięki niej zdolni kreować nasze nieświadome zachowania w sposób intencjonalny i pewny.

Przedmowa, zawierająca powyższe kluczowe informacje, została napisana przez Nicholasa Carra, profesora Uniwersytetu Richmond, wizytującego na Williams College. Jest on autorem szeregu publikacji poruszających tematy związane $\mathrm{z}$ technologią, ekonomią i kulturą. Jego książka The Shallows: What the Internet Is Doing to Our Brains z 2010 roku była nominowana do nagrody Pulitzera i pojawiła się na liście bestsellerów New York Timesa w kategorii nonficition. W przedmowie zwraca on uwagę czytelnika na coraz mniej wyraźną granicę między narzędziem a jego twórcą. Pojawia się tu również istotne określenie wytłumaczone szerzej w dalszej części książki: „delegowanie odpowiedzialności”". Jest to zjawisko polegające na tym, że decyzje takie jak: ,jaki film obejrzeć?”, ,jaką potrawę ugotować?”, czy wręcz „z kim pójść na randkę?” oddawane są programistom, a raczej stworzonym i ustawicznie aktualizowanym przez nich ,algorytmom rekomendacyjnym". Poruszone kwestie naszej relacji z takimi narzędziami jak smartfony czy internetowe aplikacje oraz wspomniane wcześniej ,delegowanie odpowiedzialności" adekwatnie wprowadzają czytelnika w tematykę książki oraz pozwalają na przejście do właściwego wprowadzenia.

Autorzy przedstawiają tutaj przykłady obrazujące problematykę, jaką będą poruszać w dalszej części publikacji. Sięgają oni do bardzo różnorodnych źródeł, chociażby do serialu Silicon Valley i dowcipnej sceny, w której jeden z bohaterów kupuje ,inteligentną lodówkę” informującą, kiedy kończy się data spożycia zakupionego przez niego jogurtu, a inna postać przejmuje kontrolę nad sprzętem i ten, zamiast informacji o konieczności uzupełnienia zapasów, wyświetla zapętlony filmik o treści nieadekwatnej dla niepełnoletniego odbiorcy. Innym przykładem jest krótki opis fenomenu osobistego asystenta Amazona - Alexy, która może m.in. odpowiadać na pytania o pogodę, zagrać nasz ulubiony utwór lub złożyć za nas zamówienie w sklepie internetowym. W publikacji znajdziemy także szero-

\footnotetext{
1 Tłumaczeń wszystkich terminów pochodzących z publikacji Frischmanna i Selingera dokonał sam autor recenzji.
} 
kie przedstawienie eksperymentu myślowego Roberta Nozicka, Experience Machine n.0. Filozof rozważa w nim, na ile popularna byłaby maszyna, która w mgnieniu oka umożliwiłaby nam przeżycie bardzo realistycznej fantazji bycia genialnym naukowcem, gwiazdą rocka czy światowej klasy atletą. Wprowadzenie zostaje zakończone krótkim opisem struktury książki.

Pierwsza część (Part I) dotyczy schematów creep phenomenon oraz slippery slope. Zostają one wykorzystane jako adekwatna metafora do opisu współczesnego procesu rozwoju technologii, przedstawionego jako zjawisko postępujące ustawicznie i niezauważalnie. Wynika to $z$ naszej coraz silniejszej więzi z narzędziami oraz wzrostem tempa, z jakim pojawiają się kolejne. Do tego stopnia, że najczęściej nawet nie zauważamy tego, że jesteśmy świadkami powstania wynalazku, który wkrótce będzie miał olbrzymi wpływ na nasze życie. Wspomniane schematy stanowią środek pobudzający czytelnika do refleksji nad trudnościami związanymi nie tylko z dostrzeżeniem, ale także, jeśli nie przede wszystkim, ze zrozumieniem zasad działania inżynierii technologiczno-społecznej. Zostają one malowniczo zobrazowane ciągiem opisów ogólnych sytuacji, dokładnych obserwacji o naturze anegdotycznej, jak również mechanizmów je wyjaśniających.

Drugą część otwiera zarys przebiegu dyskusji nad transformacyjną mocą narzędzi. Następnie, poprzez studium przypadku tzw. „elektronicznych kontraktów”, przedstawione zostaje, jak w powszechnej percepcji następuje - wydawałoby się - naturalne umniejszanie roli, znaczenia oraz zagrożeń płynących ze strony inżynierii technologiczno-społecznej. W ten sposób pojawia się kolejny temat: „technologie rozszerzające umysł" (mind extending technologies). Autorzy przedstawiają, w jaki sposób mogą one posłużyć jako specyficzne zaproszenie lub pokusa do „oddelegowania” (outsourcing) istotnych aspektów naszego działania i myślenia czy wręcz przekazania kontroli nad naszymi umysłami. Konsekutywnie przytoczone zostają trzy najważniejsze czynniki powszechnie niedostrzegalnie zwiększające współcześnie znaczenie inżynierii technologiczno-społecznej. Są to:

1) Pochwała instrumentalizacji rozumu;

2) Unaukowienie procesu kierowania ludźmi poprzez rozszerzenie idei zawartych w koncepcjach tayloryzmu do niemal wszystkich środowisk, w których się poruszamy;

3) Coraz łatwiejsze projektowanie technologii skłaniających nas do „włączenia autopilota".

W kolejnym rozdziale zaproponowany zostaje nowy schemat rozpoznawania i oceniania procesów inżynierii technologiczno-społecznej. Składa się on z dwóch kroków. Pierwszy z nich to eksperyment (empiryczny lub myślowy), który pozwala ustalić, czy w konkretnych okolicznościach jednostka zachowuje się jak ,prosta maszyna" (simple machine). Termin ten oznacza, że zastąpienie człowieka maszyną w rozważanej sytuacji nie wpłynie w żaden sposób na dany proces. Gdy uzyskamy 
odpowiedź twierdzącą, autorzy postulują wzmożenie czujności i przeprowadzenie drugiego eksperymentu (tak jak poprzednio jego natura nie jest istotna-może być zarówno empiryczny, jak i myślowy). Dzięki niemu powinniśmy być w stanie ocenić, czy dana sekwencja wydarzeń wpłynie na uczestnika negatywnie. Jeżeli odpowiedź jest twierdząca, należy zatrzymać eksperyment i przenalizować, jakie jest źródło problemu oraz jakie mamy alternatywy. Naturalnie, odpowiedź negatywna jest tożsama ze stwierdzeniem braku oporów normatywnych i możliwości kontynuowania procesu bez jakichkolwiek ingerencji w jego przebieg.

Następnie autorzy odnoszą się do testu Turinga. A raczej jego inwersji, gdyż badane tutaj jest nie tyle tworzenie inteligentnych maszyn, ile nieinteligentnych ludzi. Celem dokonania takiej ewaluacji przedstawione zostają cztery testy:

1) obliczenia matematyczne,

2) generowanie liczb losowych,

3) racjonalność,

4) zdrowy rozsądek.

Autorzy przytaczają opisy tychże doświadczeń, z wyszczególnieniem możliwych do zastosowania bodźców testujących oraz instrukcji, jak można interpretować reakcje osób badanych. Ostatnie dwa zabiegi, jako podkreślające naturalne intuicje tego, co znaczy być człowiekiem, są opisane bardziej szczegółowo.

Dalsza część trzeciego rozdziału dotyczy wolnej woli i zagrożenia, jakie grozi jej ze strony „determinizmu skonstruowanego” (engineered determinism). Wolna wola jest tutaj rozumiana jako zdolność osoby do refleksji nad swoimi przekonaniami, preferencjami, wartościami i intencjami oraz do ich ustalenia, określenia. Rozpatrując to, jak fundamentalną rolę odgrywa ona w naszej cywilizacji, zwłaszcza w podstawowych, elementarnych koncepcjach związanych z moralną odpowiedzialnością, autorzy twierdzą, że tak pojmowana nie tylko istnieje, ale ma także olbrzymie znaczenie. Rozdział ten kończy się opisem skomplikowanej relacji łączącej wolną wolę z metodami inżynierii technologiczno-społecznej.

Konkluzja trzeciej części silnie orbituje wokół jednego pytania: „W jakim celu?” („To what end?”). Inżynieria technologiczno-społeczna dotyka bezpośrednio tego, kim jesteśmy jako ludzie oraz tego, w jakim świecie chcemy żyć. To naturalne, gdyż - jak określają autorzy - jesteśmy „techno-społecznymi zwierzętami”. To, co odróżnia nas od reszty fauny, to zdolność do wyobrażania, konceptualizacji i dostosowywania otoczenia podług swoich potrzeb. Ponadto, nasze wysiłki kumulują się. Jedno pokolenie za drugim kolektywnie produkujemy, kultywujemy i podtrzymujemy wspólne koncepcje ludzkości o naturze zazwyczaj zgoła normatywnej. Każda generacja odpowiada na swój sposób na pytania o to, jak powinny zostać wykorzystane posiadane przez nas predyspozycje, jakich siebie i jakie społeczności powinniśmy kreować. W ujęciu przedstawionym przez autorów problematyczne jest aktualne podejście: oddanie poszukiwania odpo- 
wiedzi na te pytania maszynom, zoptymalizowanie ich za pomocą algorytmów i inteligentnych domów.

Ostatnia część książki jest w istocie zbiorem przepisów, rozwiązań wypracowanych przez autorów. Główną metodą postulowaną przez nich jest ,wezwanie do wolności" (call to freedom), na które składają się dwa powiązane ideały:

1) wolność od programowania, warunkowania i kontroli skonstruowanej przez innych (freedom to be off);

2) wolność woli i egzekwowania sprawczości (freedom from engineered determinism).

Po krótkim omówieniu tychże idei rozważane są strategie umożliwiające ograniczenie techno-społecznego dylematu ludzkości oraz ukierunkowanie inżynierii technologiczno-społecznej na podtrzymanie człowieczeństwa. Obejmuje to wezwanie do częstszego wykorzystywania myślenia krytycznego oraz odejście od przerzucania się danymi i językiem ściśle obliczeniowym jako głównymi metodami w dyskusjach.

Kolejną zaproponowaną strategią jest utworzenie przez godną zaufania organizację medialną (według autorów byłaby to stacja BBC) nowej platformy Social Media jako środka zaradczego na tzw. fake newsy.

Następnym poruszanym tematem jest bardziej zdecydowane egzekwowanie neutralności internetu. Rozważane są tu wręcz rozwiązania prawne. Celem takiego działania ma być uniknięcie tzw. „bąbli informacyjnych”.

Po tym zabiegu autorzy proponują odwrócenie aktualnego trendu w minimalizowaniu kosztów i maksymalizowaniu efektywności, aby skłonić ludzi do zwolnienia i przemyślenia swojego zachowania, zwłaszcza w internecie.

Ostatnią strategią zaproponowaną przez Frischmanna i Selingera jest system pięciu reform elektronicznych kontraktów, dotyczących tego, jak wchodzić w interakcję z warunkami użytkowania stron internetowych oraz odejść od bezmyślnego klikania „Akceptuję”. Ostatecznym celem badaczy jest zwiększenie świadomości użytkowników na to, co w sieci oznacza ich zgoda.

Książka kończy się krótką adnotacją o promyku nadziei w rozpaczliwej walce o autonomię myśli i działania, jakim według autorów jest ogólne rozporządzenie o ochronie danych, tj. RODO (ang. General Data Protection Regulation-GDPR). Autorzy postrzegają oddanie ludziom ich praw do dysponowania swoimi danymi jako ważny krok w zapobieżeniu inżynierii technologiczno-społecznej.

Naczelnym zagadnieniem poruszanym w książce Re-Engineering Humanity jest opisana powyżej konkluzja oraz zaproponowany przez badaczy zestaw rozwiązań. W kontekście tych metod rozpatrywane problemy sprawiają wrażenie wybranych arbitralnie, tylko po to, by wesprzeć główną tezę przedstawioną w publikacji. Zasugerowane środki wydają się skrajnie nierealistyczne. Być może to kwestia objętości - owym problemom poświęcono zdecydowanie więcej uwa- 
gi niż możliwym odpowiedziom na nie. A może jakości, gdyż metody wyjścia z impasu opisane w tak skrótowy sposób sprawiają wrażenie niedopracowanych, wręcz nieprzemyślanych, a przez to mniej możliwych do implementacji. Innym wyjaśnieniem może być dobrze opisana w publikacji kolosalna trudność w zawróceniu z obranej już przez nas technologicznej ścieżki. Cała ta - przedstawiona w bardzo przekonujący sposób - rozpaczliwa sytuacja staje się tym samym jeszcze trudniejsza do uniknięcia, a przez to dalece bardziej przygnębiająca.

\section{Bibliografia}

Frischmann Brett, Selinger Evan (2018), Re-Engineering Humanity, Cambridge. 